\title{
Mineral Microelements in Walnut Oil and their Role in the Prevention of Cardiovascular Diseases
}

\author{
MARIA RADA ${ }^{1 \#, ~ D E L I A ~ M I R A ~ B E R C E A N U-V A D U V A ~}{ }^{1 \#,}$ \\ MILAN DANIEL VELIMIROVICI ${ }^{2}$, SIMONA DRAGAN ${ }^{1}$, \\ BIANCA BERCEANU-VADUVA ${ }^{{ }^{*}}$, MARCEL MIHAI BERCEANU-VADUVA ${ }^{1}$, \\ ADINA NEGREA ${ }^{3}$, MARCEL DANCI ${ }^{4}$, DANA EMILIA VELIMIROVICI ${ }^{1 \#}$ \\ ${ }^{1}$ University of Medicine and Pharmacy Victor Babes, Faculty of Medicine, 2 Eftimie Murgu Sq., 300041, Timisoara, \\ Romania \\ ${ }^{2}$ Clinical Emergency Children's Hospital Louis Turcanu, 2 Dr. Iosif Nemoianu Str., 300011, Timisoara, Romania \\ ${ }^{3}$ Politehnica University Timisoara, Faculty of Industrial Chemistry and Environmental Engineering, 6 Vasile Parvan Str., \\ 300223, Timisoara, Romania \\ ${ }^{4}$ Banat University of Agricultural Sciences and Veterinary Medicine King Mihai I of Romania Timisoara, Department of \\ Genetic Engineering, 119 Calea Aradului, 300645, Timisoara, Romania
}

\begin{abstract}
Currently, the literature data regarding the concentration of microelements in walnut oil are low, most of them being related to their presence in the walnut core. The purpose of this study was to determine the distribution of essential and toxic mineral elements from walnut oil marketed in Timisoara (Romania) and to evaluate the mineral contribution of this important food in the prevention of cardiovascular diseases. The paper presents the results obtained in determining the content of some essential and toxic microelements of the native walnut oil, used as dietary food. The results obtained from the analysis of the essential and toxic mineral elements, by Inductively Coupled Plasma - Mass Spectrometer (ICP-MS) method, reveal that the walnut oil samples analyzed contain noticeable amounts of: $\mathrm{Fe}$ (2,576 - 3,621 $\mathrm{mg} / \mathrm{kg}), \mathrm{Mn}(1,876-1,783 \mathrm{mg} / \mathrm{kg}), \mathrm{Zn}(1,120-1,782 \mathrm{mg} / \mathrm{kg})$, low Cu $(0.185$ - $0.226 \mathrm{mg} / \mathrm{kg}), \mathrm{Cr}(0.088-0.154 \mathrm{mg} / \mathrm{kg})$ and $\mathrm{Ni}(0.052-0.081 \mathrm{mg} / \mathrm{kg})$ and very low Co $(0.001$ $0.003 \mathrm{mg} / \mathrm{kg}$ ). $\mathrm{Pb}$ and $\mathrm{Cd}$, elements with pronounced toxic potential, were identified in very low concentrations: $0.020-0.031 \mathrm{mg} / \mathrm{kg} \mathrm{Pb}$, respectively $0.001-0.002 \mathrm{mg} / \mathrm{kg} \mathrm{Cd}$. The results obtained when evaluating the mineral intake show that, under the conditions of this experiment, a daily consumption of $30 \mathrm{~g}$ of walnut oil cannot be considered as the only additional source of microelements.
\end{abstract}

Keywords: microelements, walnut oil, mineral intake

\section{Introduction}

Walnuts are consumed worldwide, being highly appreciated both for their taste and as a source of important nutrients, such as essential minerals, carbohydrates, phenolic compounds, vitamins and polyunsaturated fatty acids [1-3].

Walnut oil contains unsaturated fatty acids: linoleic (omega-6), $\alpha$-linolenic (omega-3) and oleic (omega-9) [4]. Omega-9 monounsaturated fatty acids together with omega-3 and omega-6 polyunsaturated fatty acids make up about $91 \%$ of the energy intake.

Polyunsaturated fatty acids of the omega-3 and omega-6 are precursors of eicosanoids (prostaglandins, prostacyclins, thromboxanes, leukotrienes and lipoxins) - tissue hormones with a broad spectrum of activity (e.g. an anticoagulant effect, reduction in triacylglycerol concentration, and regulation of cardiovascular function, blood pressure or inflammatory processes) [5].

However, epidemiological and clinical studies show that only omega-3 fatty acids, especially eicosapentaenoic acid and docosahexaenoic acid, have a significant role in the prevention of coronary heart disease. This is due to multiple mechanisms of action, such as reducing vasoconstriction and thrombocyte aggregation, but also because of the hypolipid and antiarrhythmic role [5, 6]. 
Essential unsaturated fatty acids have an important role in health prophylaxis, especially in prevention of cardiovascular, allergic or inflammatory diseases [5].

Bioactive compounds in walnut oil include tocopherols, carotenoids (mainly $\beta$-carotene) and phytosterols.

Data from the literature show that walnut oil contains polyphenols 1,558-1,625 mg GAE-gallic acid equivalent $/ 100 \mathrm{~g}$ ), including pedunculagin, ellagic acid, tellimagrandin I, casuarictin, tellimagranin II, casuarinin and gallic acid [5].

Clinical studies have shown that polyphenols have beneficial effects on the vascular system by improving endothelial function, increasing antioxidant capacity, inhibiting platelet aggregation and the oxidation of low density lipoprotein, lowering blood pressure and reducing inflammatory response [7].

It has been shown that the consumption of walnuts and walnut oil, containing polyphenols, has a beneficial effect in preventing the occurrence of high blood pressure, diabetes, hyperlipidemia and obesity [8]. Walnut components such as unsaturated fatty acids, L-arginine, beneficial minerals, phenolic compounds and phytosterols target multiple cardiovascular risk factors and metabolic pathways, which explain why nuts so strongly reduce cardiovascular risk [9].

In addition, phenolic compounds are naturally present in walnut oils and are the main compounds responsible for the stability of the oil during storage [10].

Walnut oil is also an important source of vitamins (F, D, E, A, K) and essential mineral elements (especially $\mathrm{K}, \mathrm{Ca}, \mathrm{Mg}, \mathrm{P}, \mathrm{Fe}, \mathrm{Mn}, \mathrm{Zn}, \mathrm{Cu}, \mathrm{Se}, \mathrm{Cr}$ ). with major implications for maintaining the health of the body. These components give the walnut oil numerous therapeutic qualities with implications for the prevention and control of numerous diseases of the cardiovascular, gastrointestinal and urinary system [11].

The inclusion of walnuts in the human diet is desirable, as they have beneficial effects on the cardiovascular system. Their consumption plays an important role in the prevention of cardiovascular diseases, but also of diabetes and cancer. Due to their nutritional and medicinal benefits, walnuts have even been considered a natural functional food [1, 12-14].

The risk factors, related to nutrition, that most affect the health status are: reduced consumption of fruits, vegetables, whole grains, fiber; reduced intake of nuts and seeds, n-3 fatty acids; deficiency of iron, vitamin $\mathrm{A}$ and zinc, as well as high sodium and processed meat [15].

Walnuts possess well-known antioxidant and anti-inflammatory bioactivity. Several studies have evaluated the potential role of walnuts against the initiation and progression of diseases such as cancer, cardiovascular and neurodegenerative diseases [16]. Regarding cardiovascular disease, a low diet in nuts and seeds was classified as the maximum risk factor for cardiac ischemic disease [15].

Clinical studies have shown the beneficial effects of nutritional diets that include nuts, such as the Mediterranean diet on cardiovascular disease risk factors, beneficially influencing lipid profile, vascular inflammation and blood pressure $[12,17]$.

The consumption of walnuts may also be beneficial for hypertensive people, as they are high in potassium, which favors the elimination of sodium, which is involved in increasing blood pressure. Copper, chromium, iron and zinc present in walnuts are essential micronutrients for human health and important for human metabolism $[1,18]$.

While the organic compounds of walnuts are well studied, there is limited recent data on the mineral composition of walnuts. Ossai showed that the concentrations of $\mathrm{Ca}, \mathrm{Mg}, \mathrm{K}, \mathrm{Fe}$ and $\mathrm{Na}$ in walnuts are higher than other elements [19].

The presence of potentially toxic elements, which come to fruition via the absorption of the root of the plant, must be taken into account when evaluating the nutritional value of the walnutsKnowing the mineral content of walnuts is therefore important not only from a nutritional point of view, but also for toxicological reasons. It must be ensured that these metals are below the respective levels PTWI (Provisional Tolerable Weekly Intake), PTDI (Provisional Tolerable Daily Apake) or PTMI (Provisional Tolerable Monthly Intake) established by FAO / WHO (2011) [20]. 
Twenty-one of the macro-, micro- and trace elements (Al, As, B, Ba, $\mathrm{Ca}, \mathrm{Cd}, \mathrm{Co}, \mathrm{Cr}, \mathrm{Cu}, \mathrm{Fe}, \mathrm{K}, \mathrm{Li}$, $\mathrm{Mg}, \mathrm{Mn}, \mathrm{Mo}, \mathrm{Na}, \mathrm{Ni}, \mathrm{Pb}, \mathrm{Se}, \mathrm{Sr}$ and $\mathrm{Zn}$ ) were determined in walnuts and walnut oils. Macroelements $\mathrm{Ca}, \mathrm{K}, \mathrm{Mg}$ and $\mathrm{Na}$ were present in nuts in significant quantities. Some micro- and trace elements (essential and non-essential) important for many metabolic and physiological functions, such as B, Ba, $\mathrm{Cd}, \mathrm{Co}, \mathrm{Cr}, \mathrm{Cu}, \mathrm{Fe}, \mathrm{Li}, \mathrm{Mn}, \mathrm{Mo} \mathrm{Ni}, \mathrm{Pb}, \mathrm{Se}, \mathrm{Sr}$ and $\mathrm{Zn}$, are present in walnuts in variable amounts (from $\mu \mathrm{g} / \mathrm{kg}$ to $\mathrm{mg} / \mathrm{kg}$ ). Regarding micro- and trace elements, the following order was found (decreasing content): $\mathrm{Mn}>\mathrm{Fe}>\mathrm{Zn}>\mathrm{B} \mathrm{Mo}>\mathrm{Cu}>\mathrm{Ni}>\mathrm{Co}>\mathrm{Al}>\mathrm{Sr}>\mathrm{Ba}>\mathrm{Li}>\mathrm{Pb}>\mathrm{Se}>\mathrm{Cr}>\mathrm{As}>\mathrm{Cd}$. In addition, the potentially toxic trace elements $(\mathrm{As}, \mathrm{Cd}, \mathrm{Pb}$ ) determined were below the maximum values allowed in most of the investigated walnut samples [1].

The concentration ranges of trace elements differ much more than those of macro-elements. As for $\mathrm{Cd}$ and $\mathrm{Cr}$, the values vary even by two or more orders of magnitude.

Whereas the major elements are mainly determined by the composition of the mother rock, where the walnut trees are grown, the soil contents of trace elements are influenced by environmental factors, such as dry and wet deposition.

Since potentially toxic metals (eg $\mathrm{Pb}$, As and $\mathrm{Cd}$ ) may enter the food chain as a result of their absorption by the walnuts, it is necessary to evaluate the levels of toxic metals and to report possible contamination that would pose a health hazard.

Even though walnut oil is considered to be very healthy and a useful supplement to the human diet, its inorganic composition is not well documented.

From the ones presented, there is considerable interest in knowing the mineral profile of the walnut oil. The determination of the elements in the edible oils is important and necessary not only for the evaluation of the nutritional contribution, but also for determining the degree of contamination with toxic metals or by-products resulting from their oxidation.

Currently, there are limited data on the concentration of microelements in walnut oil, most of them are related to their presence in walnut kernels.

The purpose of this study was to determine the distribution of essential and toxic mineral elements from walnut oil marketed in Timisoara (Romania) and to evaluate the mineral contribution of this important food in the prevention of cardiovascular diseases.

\section{Materials and method Experimental}

Samples of walnut oil were taken from three different companies producing walnut oil - Romania, Hungary and Germany, (packaged in $100 \mathrm{~mL}$ glass bottles), obtained by cold pressing (noted as Manufacturers 1- 3), recommended for consumption or for therapeutic purposes. These samples, collected during the guarantee period, were the basis for the formation of the samples $(10 \mathrm{~g})$ for the analysis of the mineral elements concerned.

The determination of mineral elements was performed by Inductively Coupled Plasma - Mass Spectrometer (ICP-MS) method [1,11].

This method has been used and recommended by Cindrić I. et al. as the method that is suitable for determining the low and very low concentrations of the microelements in the walnut oil [1].

The solubilization of the oil samples was performed by the calcination method, followed by the solubilization of the ash in $0.5 \mathrm{~N}$ nitric acid. The calcination of the oil samples, previously evaporated to dryness on the sand bath, was carried out in the NABERTHERM oven, made in Germany, Model

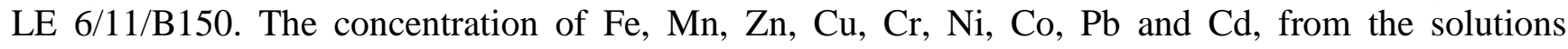
obtained after solubilization was performed using the Bruker - Aurora M90 - Quadrupole ICP-MS spectrometer. The following reagents were used: $65 \%$ super nitric acid - Merck $\left(\mathrm{d}=1.39 \mathrm{~g} / \mathrm{cm}^{3}\right)$; standard calibration solution $(1 \mathrm{~g} / 1000 \mathrm{~mL})$ of Merck purity; bidistilled water. 


\section{Statistical processing}

All analyses were carried out in triplicate. The mean and SD of each sample was calculated.

\section{Results and discussions}

Walnut seeds have a remarkable amount of minerals ( $\mathrm{Mg}$ and $\mathrm{Ca}$ being the major minerals), which are beneficial for the health of the body. The quality of walnut oils and other edible oils are directly related to the metal content. Particularly important are trace elements such as $\mathrm{Fe}, \mathrm{Cu}, \mathrm{Ca}, \mathrm{Mg}, \mathrm{Co}, \mathrm{Ni}$ and $\mathrm{Mn}$, which increase the oxidation rate of the oil, especially $\mathrm{Cu}$ and $\mathrm{Ni}$, which affect the quality by increasing its oxidative degradation.

Other toxic mineral elements such as $\mathrm{Cr}, \mathrm{Cd}$ and $\mathrm{Pb}$, important for their metabolic role but also for their toxicity, may be accidentally present in walnut oil. The content of metals and metalloids found in walnut oil is generally lower than in walnuts, indicating that the analyzed elements are mainly related to the proteins of the walnut core, and by pressing, they remain in residues.

The experimental results obtained in determining the essential and toxic elements of the walnut oil samples are presented in table 1; each value represents the average of three determinations.

Table 1. The concentration of essential and toxic trace elements in walnut oil

\begin{tabular}{|c|c|c|c|c|c|c|c|c|c|c|}
\hline \multirow{2}{*}{ Specification } & \multicolumn{8}{|c|}{ Mineral element, $\mathrm{mg} / \mathrm{kg}$ walnut oil } \\
\cline { 2 - 11 } & $\mathrm{Fe}$ & $\mathrm{Mn}$ & $\mathrm{Zn}$ & $\mathrm{Cu}$ & $\mathrm{Cr}$ & $\mathrm{Ni}$ & $\mathrm{Co}$ & $\mathrm{Pb}$ & $\mathrm{Cd}$ \\
\hline Manufacturer 1 & $3.142 \pm$ & $2.018 \pm$ & $1.120 \pm$ & $0.185 \pm$ & $0.106 \pm$ & $0.052 \pm$ & $0.002 \pm$ & $0.031 \pm$ & $0.002 \pm$ \\
& 0.323 & 0.317 & 0.203 & 0.039 & 0.034 & 0.017 & 0.000 & 0.031 & 0.000 \\
\hline Manufacturer 2 & $3.621 \pm$ & $2.502 \pm$ & $1.782 \pm$ & $0.226 \pm$ & $0.088 \pm$ & $0.081 \pm$ & $0.001 \pm$ & $0.024 \pm$ & $0.002 \pm$ \\
& 0.226 & 0.279 & 0.291 & 0.056 & 0.018 & 0.022. & 0.000 & 0.014 & 0.000 \\
\hline Manufacturer 3 & $2.576 \pm$ & $1.876 \pm$ & $1.548 \pm$ & $0.215 \pm$ & $0.154 \pm$ & $0.063 \pm$ & $0.003 \pm$ & $0.020 \pm$ & $0.001 \pm$ \\
& 0.330 & 0.312 & 0.208 & 0.042 & 0.034 & 0.018 & 0.000 & 0.010 & 0.000 \\
\hline Mean value & $3.113 \pm$ & $2.132 \pm$ & $1.483 \pm$ & $0.209 \pm$ & $0.116 \pm$ & $0.065 \pm$ & $0.002 \pm$ & $0.025 \pm$ & 0.002 \\
& 0.427 & 0.268 & 0.274 & 0.017 & 0.028 & 0.012 & 0.001 & 0.005 & \\
\hline
\end{tabular}

As can be seen from the ones presented in table 1, the distribution of the mineral elements in the walnut oil samples taken in the experiment shows a marked non-uniformity, depending on the nature of the element and the origin of the sample. The concentration of the microelements in the walnut oil is conditioned by their concentration in the walnut kernel used to obtain it and varies depending on the walnut variety, the conditions of cultivation, harvesting and storage [1].

The concentration of the analyzed mineral elements varies, having values between $0.001 \mathrm{mg} / \mathrm{kg}$ (for $\mathrm{Co}$ and $\mathrm{Cd}$ ) and $3.621 \mathrm{mg} / \mathrm{kg}$ (for $\mathrm{Fe}$ ).

The concentrations of the mineral elements determined experimentally are comparable to those obtained by other researchers, when analyzing similar vegetable oils [11,21]. Some differences can be explained by the fact that the mineral profile of walnut oils is determined by a number of factors: nut species, cultivation conditions, reaction techniques, packing and storage, etc. [21, 22].

The best represented of these microelements are Fe, Mn and $\mathrm{Zn}$. The rest of the essential elements were determined in much lower concentrations - $\mathrm{Cu}, \mathrm{Cr}$, Ni and even very low concentrations - $\mathrm{Co}, \mathrm{Pb}$ and $\mathrm{Cd}$. The elements with high toxic potential $(\mathrm{Co}, \mathrm{Pb}$ and $\mathrm{Cd})$ were determined in very low and extremely low concentrations.

The low values of the concentrations of the essential elements do not diminish by any means their importance. Their presence, even in low concentrations, play significant cardioprotective roles when they are present in adequate pharmacologic concentrations due to their antioxidant, anti-inflammatory and immune function modulatory activities [23-25].

Iron, an essential micronutrient for oxygen transport and storage, for muscle and cardiac metabolism as well as for protein synthesis and degradation [26], was determined in the highest concentrations of the analyzed elements, respectively between $2.576-3.621 \mathrm{mg} / \mathrm{kg}$. The average iron concentration in the studied walnut oil was $3.113 \pm 0.427 \mathrm{mg} / \mathrm{kg}$. Deficiency of this element is associated with anemia as well as other cardiovascular conditions (pulmonary arterial hypertension, 
heart failure) [25, 27]. Iron deficiency can lead to various biochemical and metabolic disorders that ultimately lead to aggravation of cardiovascular disease.

In the study carried out by Cindric and co-workers, the concentration of iron in the walnut oil studied ranged between 5.35-86.4 mg/kg [1].

It is well known that mineral iron is a key element for hemoglobin synthesis, as well as for the health and functioning of the body. The daily intake required depends on the age and sex of the person, for an adult male the need is about $8 \mathrm{mg}$ [28].

Manganese, another essential microelement involved in the metabolism of carbohydrates, fats and proteins [25] has been identified in concentrations ranging from $1.120-1.782 \mathrm{mg} / \mathrm{kg}$. It is present in smaller quantities compared to the average Fe concentration, but higher than the $\mathrm{Zn}$ concentration.

The average concentration of this microelement was $2.132 \pm 0.268 \mathrm{mg} / \mathrm{kg}$. Manganese is associated with some changes in heart rate and blood pressure, [24] as well as with the prevention of atherosclerosis in hypertensive patients [25].

Data from the literature indicate a concentration of manganese in walnut oil between 0.099-0.012 $\mathrm{mg} / \mathrm{kg}$, with an average of $0.041 \mathrm{mg} / \mathrm{kg}$ [1]. Manganese is considered an essential micronutrient for the human body, being necessary for the normal functioning of the brain, nervous system and many enzymatic systems.

Various studies indicate that low serum level of $\mathrm{Mn}$ is associated with atherosclerosis. A recent study by Bagheri et al. [29] reported an inverse association between serum manganese level and severity of atherosclerosis. The severity of atherosclerosis increases as the serum Mn level decreases.

Serum levels of manganese above physiologic limits have been associated with decreased myocardial contractility and abnormal electrocardiogram findings [23].

Zinc is present in all enzyme systems in the body. Zinc plays a significant role in stabilizing biological membranes, in nucleic acid biosynthesis and protein synthesis, in preservation of vascular endothelial function, and in protecting macromolecules against reactive oxygen species. Zinc deficiency is more common in patients with cardiovascular disease [23]. Low serum concentrations of $\mathrm{Zn}$ were found in hypertensive with heart disease subjects [25].

Several studies have documented an inverse relationship between serum $\mathrm{Zn}$ levels and cardiovascular disease and between serum zinc levels and cardiovascular disease risk markers, (including atherosclerosis, insulin levels, hyperuricemia and higher serum hs-CRP). Direct associations between serum $\mathrm{Zn}$ level and HDL-cholesterol, albumin and red blood cells have also been citated [23, 30, 31].

The concentration limits of this microelement in the oil samples analyzed are between $1.200-$ $1.782 \mathrm{mg} / \mathrm{kg}$. Other authors report zinc concentrations between $9.7-85 \mathrm{mg} / \mathrm{kg}$. With an average of 38.6 $\mathrm{mg} / \mathrm{kg}$. Although zinc is the microelement that was found along with iron and manganese in the highest quantity, the values are significantly lower than those found in other studies [1].

$\mathrm{Zn}$ is one of the most abundant nutritionally essential elements in the human body. $85 \%$ of whole $\mathrm{Zn}$ is found in muscles and bones, $11 \%$ in skin and liver, and the rest in all other tissues [32].

As the second most abundant transition metal ion in the human body after iron, $\mathrm{Zn}$ is considered to be an essential factor in many biological processes, such as brain function and pathology, gene transcription, immune function and mammalian reproduction [33].

Cooper, an essential microelement whose deficiency is associated with several cardiovascular diseases, arteriosclerosis, CAD, including myocardial infarction, congestive cardiac failure.

Several mechanisms underlie copper-deficiency induced cardiovascular disease, including abnormal functioning of copper-dependent enzymes (cytochrome $\mathrm{C}$ oxidase, lysyl oxidase, ceruloplasmin, peptidylglycine $\alpha$-amidating mono-oxygenase and dopamine $\beta$-mono-oxygenase), glycation, peroxidation, and defective $\mathrm{NO}$ activities [23]. $\mathrm{Cu}$ also plays an anti-inflammatory, antiinfectious and antiviral role [34].

In the studied walnut oil $\mathrm{Cu}$ was determined within the limits of concentrations between 0.185 $0.226 \mathrm{mg} / \mathrm{kg}$, and the average concentration of this element was $0.209 \pm 0.017 \mathrm{mg} / \mathrm{kg}$. 
Similar concentrations of $\mathrm{Cu}$ in walnut oil were also detected in the study by Cindrič et al., 0.073$0.529 \mathrm{mg} / \mathrm{kg}$ [1].

Trivalent chromium is an essential mineral that plays a significant role in lipid and carbohydrate metabolism [35]. It constitutes part of the glucose/insulin-complex system, otherwise known as glucose tolerance factor, and acts as a critical cofactor in the action of insulin [36].

The insulin resistance induced by chromium deficiency is considered to be a risk factor for the occurrence of dyslipidemia and hyperglycemia. It is well known that these metabolic disorders are associated with the risk of cardiovascular disease occurring in the general population. The trivalent Studies by and Newman et al. [37,38] show that a plasma chromium level $<0.06 \mu \mathrm{g} / \mathrm{L}$ is strongly associated with CAD risk.

Insulin resistance also leads to other risk factors for adverse cardiovascular events such as hypertension, dyslipidemia, hyperuricemia and obesity [23]. In patients with atherosclerosis, myocardial infarction and peripheral vascular disease, high insulin levels were detected [39].

The trivalent chromium was determined in small amounts, between $0.088-0.154 \mathrm{mg} / \mathrm{kg}$ in the analyzed walnut oil. Similar amounts of Cr trivalent $0.002-0.152 \mathrm{mg} / \mathrm{kg}$ have also been reported by other authors who determined microelements such as $\mathrm{Cr}$ in walnut oil [1].

Determination of this microelement is important because too high concentrations of $\mathrm{Cr}$ can lead to complications affecting different organ systems, and long-term exposure can even cause DNA mutations [40].

Nickel, an essential microelement only in very small quantities [41], has been identified in concentrations of: $0.052-0.081 \mathrm{mg} / \mathrm{kg}$.

Other studies have determined walnut oil concentrations of $0.0070-0.069 \mathrm{mg} / \mathrm{kg}$ [1].

Although the biological function of nickel is still unclear in the human body, nickel is found in higher concentrations in nucleic acids, especially RNA, and is thought to be involved in the structure or function of proteins. It is considered that nickel could play a role, as a cofactor, in activating certain enzymes involved in the breakdown or use of glucose [26].

When nickel absorption is too high, it can become harmful to health, having a hematotoxic, immunotoxic, neurotoxic, pulmonary, nephrotoxic, hepatotoxic and carcinogenic effect [42].

Cobalt is an essential microelement, a major component of vitamin B12, but also a cofactor of enzymes involved in DNA biosynthesis and amino acid metabolism [43]. In the analyzed samples, the cobalt was determined in extremely low concentrations: $0.001-0.003 \mathrm{mg} / \mathrm{kg}$, so the walnut oil analyzed does not show interest in terms of the contribution of Co. The values obtained are similar to those obtained by other authors, who reported Co values between $0.0009-0.0029 \mathrm{mg} / \mathrm{kg}$ [1].

Knowing the concentration of this element is important because exposing the body to concentrations above normal limits can cause subacute cardiomyopathy with impaired cardiac systolic function that requires differential diagnosis with other forms of dilative cardiomyopathy. The onset of cobalt-induced cardiomyopathy seems to require the coexistence of one or more cofactors, in particular a low-protein diet, thiamine deficiency, hypothyroidism and alcoholism [44].

Lead $(\boldsymbol{P b})$ and cadmium $(\boldsymbol{C d})$, elements with pronounced toxic properties for the human body, cause both acute and chronic poisoning, adverse effects on the kidney, liver, heart, vascular and immune systems $[24,25]$. The european legislation limits the concentrations of lead and cadmium in vegetable oils to maximum values of $0.1 \mathrm{mg} / \mathrm{kg}$ for $\mathrm{Pb}$, respectively $0.05 \mathrm{mg} / \mathrm{kg} \mathrm{Cd}$ [45]. Their concentrations have very low and extremely low values, between $0.020-0.031 \mathrm{mg} / \mathrm{kg} \mathrm{Pb}$, respectively $0.001-0.002 \mathrm{mg} / \mathrm{kg} \mathrm{Cd}$, well below the limit allowed by European legislation.

Another study found $\mathrm{Pb}$ values of $0.077-0.335 \mathrm{mg} / \mathrm{kg}$, respectively Cd up to $0.0032 \mathrm{mg} / \mathrm{kg}$ [1]. Regarding the distribution of the mineral elements analyzed in the walnut oil samples, the average values of their concentrations show the following decreasing trend: $\mathrm{Fe}>\mathrm{Mn}>\mathrm{Zn}>>\mathrm{Cu}>\mathrm{Cr}>\mathrm{Ni}>>$ $\mathrm{Pb} @ \mathrm{Co}>\mathrm{Cd}$.

The average concentrations of the essential elements (table 1) allowed to evaluate the mineral intake for a daily consumption of 30 grams of oil (the equivalent of $50 \mathrm{~g}$ walnut kernel). 
When evaluating the mineral intake of walnut oil, a daily consumption of $30 \mathrm{~g}$ of walnut oil was taken into account, considering that the contents of $\mathrm{Fe}, \mathrm{Mn}, \mathrm{Zn}, \mathrm{Cu}, \mathrm{Cr}, \mathrm{Ni}, \mathrm{Co}, \mathrm{Pb}$ and $\mathrm{Cd}$ present in the $30 \mathrm{~g}$ of oil is below the permissible tolerance limits (table 4) [45].

This aspect was also agreed by Cindrić et al. who, when determining mineral and toxic elements of walnut and walnut oil, reported that he "did not observe any harmful impact of these elements by consuming up to $100 \mathrm{~g}$ of walnuts per day" [1]. Under the conditions of the present experiment, $30 \mathrm{~g}$ of walnut oil contain, on average: $0.093 \mathrm{mg} \mathrm{Fe}, 0.064 \mathrm{mg} \mathrm{Mn}, 0.045 \mathrm{mg} \mathrm{Zn}, 0.006 \mathrm{mg} \mathrm{Cu}, 0.003 \mathrm{mg} \mathrm{Cr}$, insignificant amounts of $\mathrm{Ni}$ and $\mathrm{Co}$ and extremely small amounts of $\mathrm{Pb}$ and $\mathrm{Cd}$.

Taking into account the daily requirement of mineral elements, recommended by the Food and Nutrition Board, Institute of Medicine, National Academies, for persons between the ages of 19-50 years [46] (Table 2) consumption 30 grams of oil/day (in the form of salads, sauces, etc.), covers a small part of the necessities of Fe, Mn, Zn, Cu and Cr. (Table 3).

Table 2. Reference values of the necessary $\mathrm{Fe}, \mathrm{Mn}, \mathrm{Zn}, \mathrm{Cu}$ and $\mathrm{Cr}$ in the daily-recommended diet

\begin{tabular}{|c|c|c|c|c|c|}
\hline \multirow{2}{*}{ Specification } & \multicolumn{5}{|c|}{ Recommended necessary intake (mg/day) } \\
\cline { 2 - 6 } & $\mathrm{Fe}$ & $\mathrm{Mn}$ & $\mathrm{Zn}$ & $\mathrm{Cu}$ & $\mathrm{Cr}$ \\
\hline Men aged, 19-50 & 8 & 2.3 & 11 & 0.900 & 0.035 \\
\hline Women aged, 19-50 & 18 & 1.8 & 8 & 0.900 & 0.025 \\
\hline
\end{tabular}

Table 3. Mineral intake corresponding to a consumption of $30 \mathrm{~g}$ walnut oil/day

\begin{tabular}{|c|c|c|c|c|c|}
\hline \multirow{2}{*}{ People range } & \multicolumn{5}{|c|}{ Mineral supply (\%) } \\
\cline { 2 - 6 } & $\mathrm{Fe}$ & $\mathrm{Mn}$ & $\mathrm{Zn}$ & $\mathrm{Cu}$ & $\mathrm{Cr}$ \\
\hline Men aged, 19-50 & 1.17 & 2.78 & 0.40 & 0.70 & 9.94 \\
\hline Women aged, 19-50 & 0.52 & 3.55 & 0.56 & 0.70 & 13.92 \\
\hline
\end{tabular}

The data presented in table 3 shows that a daily consumption of $30 \mathrm{~g}$ of walnut oil (in the form of sauce, salad, etc.) covers only a small part of the daily requirement of $\mathrm{Fe}, \mathrm{Mn}, \mathrm{Zn}, \mathrm{Cu}$ and to a greater extent from $\mathrm{Cr}$. It can be seen that a daily consumption of $30 \mathrm{~g}$ of oil provides between $9.94-13.92 \%$ of the $\mathrm{Cr}$ requirement for men and women.

Under these conditions, the analyzed walnut oil cannot be considered as the only additional source of microelements, although it contains appreciable amounts of $\mathrm{Fe}, \mathrm{Mn}, \mathrm{Zn}$ and less $\mathrm{Cu}$ and $\mathrm{Cr}$. These values may be somewhat explained by the reduced amount of oil consumed, as compared to other foods consumed in larger quantities.

Because the concentrations of the essential microelements in the $30 \mathrm{~g}$ of walnut oil (Table 4) are well below the tolerance limits allowed by the Food and Nutrition Board, National Academies of Sciences, Engineering, and Medicine [47], the amount of oil can be supplemented by obtaining thus, an increase in mineral intake.

Table 4. The content of essential microelements in $30 \mathrm{~g}$ of walnut oil compared with the tolerable limits allowed (men and women between the ages of 19 and 50)

\begin{tabular}{|c|c|c|c|c|c|c|c|}
\hline \multirow{2}{*}{ Specification } & \multicolumn{7}{|c|}{ Esential microelements } \\
\cline { 2 - 8 } & $\mathrm{Fe}$ & $\mathrm{Mn}$ & $\mathrm{Zn}$ & $\mathrm{Cu}$ & $\mathrm{Cr}$ & $\mathrm{Ni}$ & $\mathrm{Co}$ \\
\hline The tolerated amount, mg/day & 45 & 11 & 40 & 10 & $\begin{array}{c}\text { Not } \\
\text { determined }\end{array}$ & 1 & - \\
\hline $\begin{array}{c}\text { Microelements content (mg) } \\
\text { in 30g oil }\end{array}$ & 0.093 & 0.064 & 0.045 & 0.006 & 0.003 & 0.002 & 0.000 \\
\hline
\end{tabular}

Further oil consumption needs to be done with great care as an excess of oil brings with it compounds and compounds that can be harmful over certain concentration limits.

Dietary changes remain the cornerstone for the prevention and treatment of cardiovascular 
disease. Patients with cardiovascular disease generally present a cumulative of both unmodifiable and modifiable cardiovascular risk factors, and currently the metabolic syndrome is frequently associated with hyperuricemia. In the treatment of hyperuricemia, a diet rich in vegetables and fresh fruits is recommended $[48,49]$. There is convincing evidence that a cardio-protective diet that includes nuts is an important lifestyle practice for managing the risk of cardiovascular disease [50]. Walnut consumption 1-4 times/week was associated with a 30\% decrease in the risk of cardiovascular disease [15].

Nut consumption (42.5-85 g/day) has been shown to lower serum levels of both total cholesterol and LDL-cholesterol, lower blood pressure, improve endothelial function, decrease both oxidative stress and inflammation markers [51]

The European guideline for the prevention of cardiovascular disease recommends a daily intake of $30 \mathrm{~g}$ of unsalted nuts, an indication resulting from a meta-analysis of cohort studies that showed a reduction in the risk of cardiovascular disease by $30 \%[52,53]$.

Data from the literature have shown that frequent walnut consumption is associated with improved risk factors for cardiovascular disease $[54,55]$ and with a lower risk of developing cardiovascular disease [56, 57]. Clinical studies have reported beneficial effects of walnut consumption on blood lipids [48], inflammatory parameters, insulin resistance [57, 58] and blood pressure [59]. Walnuts are a good source of unsaturated fatty acids and are rich in fiber, minerals (potassium, calcium and magnesium), vitamins (folate and E), phytosterols and polyphenols [58].

Frequent consumption of walnuts and/or walnut oil (which is usually how walnut products are consumed) can improve cardiovascular risk through mechanisms that extend beyond the established action of reducing cholesterol [60].

From the ones presented, there is considerable interest in knowing the mineral profile of the walnut oil. The determination of the elements in the edible oils is important and necessary not only for the evaluation of the nutritional contribution, but also for determining the degree of contamination with toxic metals or by-products resulting from their oxidation.

\section{Conclusions}

Comparison of the metal content of oils and nuts leads to useful information for nutritional science.

The experimental results obtained in the analysis of the essential mineral microelements show that the walnut oil samples analyzed contain noticeable amounts of $\mathrm{Fe}, \mathrm{Mn}$ and $\mathrm{Cu}$, low contents of $\mathrm{Cu}, \mathrm{Cr}$ and $\mathrm{Ni}$ and insignificant of $\mathrm{Co}$. Toxic elements: $\mathrm{Pb}$ and $\mathrm{Cd}$ were identified in very small quantities, below the allowed toxicity limit.

The data obtained when evaluating the mineral intake show that a daily consumption of 30 grams of walnut oil covers only a small part $(0.52 \%-3.55 \%)$ of the daily requirement of $\mathrm{Fe}, \mathrm{Mn}, \mathrm{Zn}, \mathrm{Cu}$, respectively $9.94-13.92 \%$ of the daily requirement of $\mathrm{Cr}$ for men and women.

Under the conditions of the present experiment, the walnut oil analyzed cannot be considered as an additional single source of mineral microelements, but it can be recommended, as well as the food consumption as a dietary mineralizing food.

Modifying the diet remains essential for the prevention and treatment of cardiovascular disease, with evidence that a cardioprotective diet that includes nuts is an important lifestyle practice for managing the risk of cardiovascular disease.

\section{References}

1.JURANOVIĆ CINDRIĆ, I., ZEINER, M., HLEBEC, D. Int. J. Environ. Res. Public Health, 15, no.12, 2018, p. 2674.

2.GECGEL, U., GUMUS, T., TASAN, M., DAGLIOGLU, O., ARICI, M. Radiat. Phys. Chem, 80, no. 4, 2011, p. 578.

3.CHRISTOPOULOS, M.V., TSANTILI, E., Eur. J. Lipid Sci. 117, no. 3, 2015, p. 338. 
4.POGGETTI, L., FERfuiA, C., CHIABÀ, C., TESTOLIN, R., BALDINI, M., J. Sci. Food Agric. 98, no. 3, 2018, p. 955.

5.MICHALAK, M., KIEŁTYKA-DADASIEWICZ, A., J. Oleo Sci. 68, no. 2, 2019, p. 111.

6.RABRENOVIC, B., DIMIC, E., MAKSIMOVIC, M., SOBAJIC, S., GAJIC-KRSTAJIC,L., Czech J. Food Sci., 29, no. 1, 2011, p. 74.

7.GIGLIO, R.V., PATTI, A.M., CICERO, A.F.G., LIPPI, G., RIZZO, M., TOTH, P.P., BANACH, M. Curr Pharm Des. 24, no.2,2018, p.239

8.CHENG, C.Y., SHEEN, M.J., HU, L.W., HUNG, C.Y. Hindawi Oxidative Medicine and Cellular Longevity. Volume 2017, Article ID 8526438, 16 pages https://doi.org/10.1155/2017/8526438)

9.ROS, E., British Journal of Nutrition, 113, 2015, S111-S120.

10.GROSSO, A.L., ASENSIO, C.M., NEPOTE, V., GROSSO, N.R., J Am Oil Chem Soc, 95, 2018, p. 1409.

11.GOGOAŞĂ, I., CIONTOŞ, C., COSTESCU, C., NEGREA, A., AldA, L.M., RADA, M., VELIMIROVICI, D., ALDA, S., DANCI, M., Journal of Horticulture, Forestry and Biotechnology, 20, no.3, 2016, p. 27.

12.BANEL, D.K., HU, F.B., Am. J. Clin. Nutr., 90, no. 1, 2009, p. 56.

13.JIMÉNEZ-COLMENER, F., SÁNCHEZ-MUNIZ, F.J., OLMEDILLA-ALONSO, B., Food Chem. 123, no.4, 2010, p. 959.

14.DRAGAN, S., BULEU, F., CHRISTODORESCU, R., COBZARIU, F., IURCIUC, S., VELIMIROVICI, D., XIAO, J., LUCA, C. T., Journal Critical Reviews in Food Science and Nutrition, 59, no. 6, 2019, p. 965.

15.KRIS-ETHERTON, PM., J. Nutr. 144, no. 4, 2014, p. 547S.

16.TABASUM, F., SHOWKAT, U., ZAMEER HUSSAI, S., Journal of Pharmacognosy and Phytochemistry 7, no. 2, 2018, p.1269.

17.FITO', M., GUXENS, M., CORELlA, D., SÁEZET, T.G., Arch Intern Med, 167, no.11, 2007, p.1195.

18.SCHERZ, H., KIRCHHOFF, E., J. Food Compos. Anal, 19, no. 5, 2006, p.420.

19.OSSAI, E.K. Pakistan J. Nutr. 14, no. 2, 2015, p. 84.

20.FAO/WHO. Food Standards Programme Codex Committee on Contaminants in Foods; Fifth Session; FAO/WHO: The Hague, The Netherlands, 2011

21.NNOROM, I.C., EWUZIE, U., Asian Journal of Plant Science and Research, 5, no. 4, 2015, p. 22

22.UZUNOVA, G., PERIFANOVA-NEMSKA, M., STOJANOVA, M., GANDEV, S.T., Journal of Agricultural Science, 21, no. 3, 2015, p. 494.

23.EKPENYONG, C.E., Int. J. Nutr. Food Sci., 6, no.2, 2017, p. 53.

24.MEHRI, A., MARJAN, R.F., Int. j. Med. invest., 2, no. 3, 2013, p.115.

25.ABDULLAH, E.J., International Journal of Science and Research (IJSR), 6, no. 6, 2017, p. 972.

26.AL-FARTUSIE, F.S., MOHSSAN,S.N., Indian Journal of Advances in Chemical Science, 5, no. 3 , 2017, p. 127.

27.LAPICE, E., MASUlli, M., VACCARO, O., Iron Deficiency and Cardiovascular Disease: An Updated Review of the Evidence, Curr Atheroscler Rep, 15, no. 10, 2013, p. 358

28.KABIRI, G., BOUDA, S., ELHANSALI, M., HADDIOUI, A., Acta Scientiarum. Biological Sciences, v. 41, e46411, 2019 ISSN on-line: 1807-863X Doi: 10.4025/actascibiolsci.v41i1.46411

29.BAGHERI, B., SHOKRZADEH, M., AKBARI, N., MOKHBERI, V., AZIZI, S., KHALLIIAN, A., NABATI, M., DABIRIAN, M., PIRAN, R., Zahedan J Res Med Sci [ZJRMS], 17, no.1, 2015, p.30. 30.ISLAMOGLU, Y., EVLIYAOGLU, O., TEKBAS, E., CIL, H., ELBEY, M., Biol Trace Elem Res 144, no. 1-3, 2011, p.436.

31.TSUBOI, A., TERAZAWA WATANABE, M., KAZUMI, T., FUKUO, K., Asia Pac J Clin Nutr 23, no. 4, 2014, p. 239.

32.TAPIERO, H., TOWNSEND, D., TEW, K., Biomed Pharmacother, 57, no. 9, 2003, p.386.

33.XU, Z., YOON, J., SPRING, DR., Chem Soc Rev 39, no. 6, 2010, p. 1996. 
34.NEAMTU, G., CAMPEANU, GH., SOCACIU, C., Mineral Metabolism (Metabolismul mineral), In: Biochimie vegetala. (Eds.). Did. Ped. Bucuresti, 1995, p. 243-271

35.PRESS, R.I., GELLER, J., EVANS, G.W., Western J Med, 152, no. 1, 1990, p. $41 .$.

36.KIMURA, K., Nippon Rinsho, 54, no. 1, 1996, p. 79.

37.NEWMAN, A.I., LEIGHTON, R.F., LANESE, R.R., FREEDLAND, N.A., Clin. Chem. 24, 1978, p.541.

38.SIMONOFF, M., LLABADOR, Y., HAMON, C., PEERS, A.M., SIMONOFF, G.N., Biol Trace Elem Res, 6, no. 5, 1984, p. 431-439.

39.WATTS, D.L., J Orthomolecular Med, 4, no, 2, 1989, p. 99.

40.JAGANNATI, M., RAMYA, I., SATHYENDRA, S., Indian J Occup Environ Med., 20, no. 3, 2016, p. 150.

41.EFTEKHARI, M. H., MOZAFFARI-KHOSRAVI, H., SHIDFAR, F., ZAMANI, A., Int J Prev Med., 4, no. 8, 2013, p. 911.

42.DAS, K.K., REDDY, C., BAGOJI, I.B., DAS, S., BAGALI, S., MULLUR, L., KHODNAPUR, J.P., BIRADAR, M.S., J. basic Clin Physiol and Pharmacol, 30, no. 2, 2018, p. 141.

43.SOETAN, K.O., OLAIYA, C.O., OYEWOLE, O.E., African Journal of Food Science, 4, no. 5, 2010, p. 200.

44.PACKER, M., Circ Heart Fail., 9, no. 12, 2016, e003604

45.FARZIN, L., MOASSES, M. E., Journal of Applied Chemical Research, 8, no. 3, 2014, p.35.

46.***http://nationalacademies.org/hmd/ /media/Files/Report\%20Files/2019/DRI-Tables-

2019/2_RDAAIVVE.pdf?la=en

47.***http://www.nationalacademies.org/hmd/ /media/Files/Report\%20Files/2019/DRI-Tables-

2019/6_DRIValues_Summary.pdf?la=en

48.VELIMIROVICI, D.E., RADA, M., BERCEANU VADUVA, D.M., VELIMIROVICI, M.D., DRAGAN, S., DUDA SEIMAN, D.M., CIPU, D., DUDA SEIMAN, C., STANCU, A., BERCEANU VADUVA, M.M. Rev. Chim., 69, (11), 2018, 3018.

49.RADA,M., BERCEANU-VADUVA, D., VELIMIROVICI, M., DRAGAN, S., DUDA-SEIMAN, D., BERCEANU-VADUVA, M., DUDA-SEIMAN, C., TUDORAN, M., VELIMIROVICI, D. Rev. Chim. , 70, (3), 2019, 1062.

50.MOZAFFARIAN, D., APPEL, L.J., VAN HORN, L., Circulation, 123, no. 24, 2011, p. 2870.

51.SABATE, J., ODA, K., ROS, E., Arch Intern Med., 170, no. 9, 2010, p. 821.

52.PIEPOLI, F.M., HOES, A.W., AGEWALL S., European Heart Journal, 37, no. 29, 2016, p. 2315.

53.LUO, C., ZHANG, Y., DING, Y., SHAN, Z., CHEN, S., YU, M., HU, F.B., LIU, L., .Am J Clin Nutr., 100, no.1, 2014, p. 256-269.

54.DEL GOBBO, L.C., FALK, M.C., FELDMAN, R., LEWIS, K., MOZAFFARIAN, D., Am J Clin Nutr., 102, no.6, 2015, p. 1347.

55.GUASCH-FERRÉ, M., LI, J., HU, F.B., SALAS-SALVADÓ, J., D. K., Am J Clin Nutr, 108, no. 1, 2018, p.174.

56.AUNE, D.N., GIOVANNUCCI, E., FADNES, L.T., BOFFETTA, P., GREENWOOD, D.C., TONSTAD, S., VATTEN, L.J., RIBOLI, E., NORAT, T., BMC Med, 14, no.1, 2016, p. 207.

57.CASAS-AGUSTENCH, P., BUllO, M., SAlAS-SALVADO, J., Asia Pac J Clin Nutr, 19, no.1, 2010, p. 124.

59.ROS, E., TAPSELL, L.C., SABATE, J., Curr Atheroscler Rep, 12, No.6, 2010, p.397.

59.MOHAMMADIFARD, N. SALEHI-ABARGOUEI, A., SALAS-SALVADÓ, J., GUASCHFERRÉ, M., HUMPHRIES, K., SARRAFZADEGAN, N., Am J Clin , 101, no.5, 2015, p.966.

60.ERRYMAN,C.E., GRIEGER, J.A., WEST, S.G., CHUNG-YEN O. CHEN,V.Y.O, BLUMBERG, J.B., ROTHBLAT, G.H., SANKARANARAYANAN, S., KRIS-ETHERTON, P.M.,. J. Nutr., 143, no. 6,2013, p. 788 .

Manuscript received: 10.04 .2020 
